\title{
The role of abiotic and biotic environmental factors in shaping epiphyton on common reed in shallow, hydrologically transformed, temperate lakes
}

\author{
Magdalena Toporowska*, Jacek Rechulicz, Małgorzata Adamczuk and Michał Niedźwiecki \\ Department of Hydrobiology and Protection of Ecosystems, University of Life Sciences in Lublin, Dobrzańskiego 37, \\ 20-262 Lublin, Poland
}

\begin{abstract}
Epiphytic algae are an important group of organisms involved in primary productivity, nutrient cycling, and energy transfer in littoral food webs. However, multifactorial studies conducted on epiphyton on the same substrate across a spectrum of environmental parameters are very limited. Here, we present first complex field study on the role of abiotic and biotic factors in shaping the species richness, diversity, abundance, and biomass composition of epiphyton on common reed in four shallow lakes with different trophic status, water and fish management, and the abundance and structure of potential algal grazers: littoral crustaceans and fish. The obtained results revealed that the algal taxa richness was the lowest in the hypertrophic lake and the highest in the meso-eutrophic lake. Epiphyton abundance (predominated by pennate diatoms) and biomass were found to be the highest in eutrophic water bodies. Biomass consisted primarily of diatoms, but we found the seasonal predominance of filamentous Chlorophyta (in the eutrophic lakes) and Chlorophyceae (in the meso-eutrophic lake). Redundancy analysis (RDA) showed that the frequency of water level fluctuations was the most significant variable in the composition of epiphyton. RDA also revealed the importance of grazing pressure of fish. Thus, in hydrologically transformed lakes, man-made factors may be of great relevance in the development of epiphytic algae.
\end{abstract}

Keywords: Epiphyton abundance / biomass / diversity / algal grazers / TSI index

Résumé - Le rôle des facteurs environnementaux abiotiques et biotiques dans la formation de l'épiphyton sur le roseau commun dans les lacs tempérés peu profonds et modifiés sur le plan hydrologique. Les algues épiphytiques constituent un groupe important d'organismes impliqués dans la productivité primaire, le cycle des éléments nutritifs et le transfert d'énergie dans les réseaux trophiques littoraux. Toutefois, les études multifactorielles menées sur l'épiphyton sur le même substrat portant sur un éventail de paramètres environnementaux sont très limitées. Nous présentons ici une première étude de terrain complexe sur le rôle des facteurs abiotiques et biotiques dans la formation de la richesse, de la diversité, de l'abondance et de la composition de la biomasse de l'épiphyton sur les roseaux communs dans quatre lacs peu profonds ayant différents statuts trophiques, gestion de l'eau et des poissons, ainsi que l'abondance et la structure des brouteurs d'algues potentiels: crustacés littoraux et poissons. Les résultats obtenus ont révélé que la richesse taxonomique des algues était la plus faible dans le lac hyper-eutrophe et la plus élevée dans le lac méso-eutrophe. L'abondance de l'épiphyton (dominée par les diatomées pennées) et la biomasse étaient les plus élevées dans les plans d'eau eutrophes. La biomasse se composait principalement de diatomées, mais nous avons trouvé la dominance saisonnière de Chlorophyta filamenteux (dans les lacs eutrophes) et de Chlorophyceae (dans le lac méso-eutrophique). L'analyse de redondance a montré que la fréquence des fluctuations du niveau d'eau était la variable la plus importante dans la composition de l'épiphyton. La RDA a également révélé l'importance de la pression exercée par le broutage des poissons. Ainsi, dans les lacs transformés par l'hydrologie, les facteurs anthropiques peuvent jouer un rôle important dans le développement des algues épiphytes.

Mots-clés : Abondance de l'épiphyton / biomasse / diversité / brouteurs d'algues / index TSI

\footnotetext{
*Corresponding author: magdalena.toporowska@up.lublin.pl
} 


\section{Introduction}

Epiphyton is one of the most important biotic components in shallow lakes with extensive littoral zones (Lowe, 1996). Epiphytic algae are involved in primary productivity, nutrient cycling, and energy transfer in littoral food webs (Abe et al., 2007; Tarkowska-Kukuryk, 2013). They can decrease the growth and production of submerged macrophytes as they provide increased shading (Takashi et al., 2004). Some epiphytic diatoms and cyanobacteria are good indicators of changes of environmental factors, for example, physicochemical parameters, which determine the quality and trophic state of lake waters (Kitner and Poulícková, 2003; Blanco et al., 2014).

Both abiotic and biotic environmental factors such as light, water temperature, nutrient concentration, wave action, as well as grazing pressure affect epiphyton structure and control its productivity (Hillebrand, 2002; Gross et al., 2003; Bowes et al., 2007; Song et al., 2007; Toporowska et al., 2008; de et al., 2015), but the importance and contribution of each factor is difficult to evaluate (Lowe, 1996). An architecture and substratum of plants may also influence the growth of attached algae (Messyasz and Kuczyńska-Kippen, 2006; Toporowska et al., 2008). For example, Stratiotes aloides and Potamogeton lucens provided better habitat conditions for higher numbers of epiphytic taxa, abundances and epiphyton standing crop than Ceratophyllum demersum and Chara spp. in a macrophytedominated lake (Toporowska et al., 2008). The algal growth may also result from allelopathic activity of some macrophytes. For example, $P$. lucens produces allelochemicals that affected the biomass and community structure of phytoplankton (Kufel et al., 2007). Multifactorial studies that assess algal development on the same substrate across a spectrum of abiotic and biotic factors are either very limited (Lalonde and Downing, 1991; Hansson, 1992) or are based on experiments (Hillebrand, 2002; Poulíčková et al., 2006). Data with respect to the influence of nutrients on the structure, abundance, and biomass of epiphytic algae are often contradictory (Lalonde and Downing, 1991; Messyasz and Kuczyńska-Kippen, 2006; Bowes et al., 2007). Furthermore, a meta-analysis of 85 experimental studies showed that grazing by invertebrates on algae were found to be greater than nutrient effects (Hillebrand, 2002). In general, the reports on the role of zooplankton and fish in shaping epiphyton communities are scarce and mostly experimental (Tall et al., 2006; Abe et al., 2007; Blanco et al., 2008; Guariento et al., 2010). Some anthropogenic disturbances, like man-made water level fluctuations (WLFs), eutrophication or water pollution are also important factors that influence epiphyton (Barbour et al., 1999; Kernan et al., 2010; Pfeiffer et al., 2015). Hydromorphological modifications of lakes, which allow manipulation of water level, may strongly affect epiphyton on emergent macrophytes. For example, WLFs caused changes in the structure of epiphyton on Schoenoplectus californicus (Rodríguez et al., 2011). It seems that complex field studies of various abiotic and biotic factors might be a good supplement of experimental studies and enhance our understanding of the ecology of epiphytic algae in shallow lakes in a better way than studies of particular factors.

Herein, we present a comparative study of the community structure of epiphytic algae on common reed (Phragmites australis) in hydro-morphologically modified lakes which differ one from another with: trophic status, structure of phytoplankton and macrophyte communities, structure and use of their catchments, and water level and fish management. We hypothesized that WLFs and grazing pressure of fish are important factors that shape epiphytic algal communities in shallow lakes. This article also contributes to the knowledge about the ecology of epiphytic algae on common reed, which is a high-impact invasive species (Weis and Weis, 2003) outside of its native range (e.g., in North America).

\section{Materials and methods}

\subsection{Study area}

This study was performed in four lakes (Krzczeń, Tomaszne, Czarne Sosnowickie, Skomielno) located between $51^{\circ} 23^{\prime} 54^{\prime \prime}-51^{\circ} 30^{\prime} 56^{\prime \prime} \mathrm{N}$ and $22^{\circ} 55^{\prime} 59^{\prime \prime}-23^{\circ} 01^{\prime} 39^{\prime \prime} \mathrm{E}$ in the Łęczna-Włodawa Lake District (Polesie Region, Eastern Poland, Fig. 1). In 1961, the lakes were modified into storage reservoirs and were connected by an artificial canal supplying nutrient-rich waters from Wieprz River (Dawidek et al., 2004). The lakes differ in trophic status, structure of phytoplankton, and macrophyte communities, as well in the structure and use of their catchments. The hypertrophic Lake Krzczeń, the eutrophic Lake Tomaszne, and the meso-eutrophic Lake Skomielno (Tab. 1) are shallow and polymictic reservoirs with agricultural catchments. Lake Czarne Sosnowickie (hereafter called Czarne Sosn.) is the most natural (forest catchment; peatbog bordering the lake to the south) and the deepest, dimictic, eutrophic water body with brown-coloured water. The structure of the macrophyte communities in the lakes were described by Sender $(2012,2016)$ and Mieczan et al. (2016). The highest phytolittoral zone occurs in Lake Skomielno, where 15 plant assemblages is represented by 55 species, and common reed comprises ca. $40 \%$ of the plant biomass in the shallow parts of the lake (up to $0.5 \mathrm{~m}$ depth). The smallest phytolittoral occurs in Lake Czarne Sosn. where emergent macrophytes are represented by Typha angustiforma and $P$. australis (Sender, 2016). In Lakes Krzczeń and Tomaszne, perennial blooms of toxigenic cyanobacteria occur (PawlikSkowrońska and Toporowska, 2016). Lakes differ in water management. In Lakes Skomielno and Krzczeń, water loss occurs naturally by evaporation and the lakes are refilled twice a year (in spring and autumn) with water from the above mentioned canal (Suchora, 2012; Pawlik-Skowrońska and Toporowska, 2016). This process is controlled by the Regional Management Office for Irrigation and Water Systems in Lublin. In Lake Tomaszne, the needs of adjacent fish ponds require outflows and re-fillings three to four times a year. The lakes have never dried out completely or sufficiently to affect fish populations, which are managed by man (Tab. 1).

\subsection{Sampling, identification, and enumeration of epiphytic algae}

Common reed (P. australis) is an emergent macrophyte with an essential share in a cover of the emergent plants which achieve of $13-49 \%$ of the lake area in the studied lakes (Tab. 1, Sender, 2012; 2016). Epiphytic algae on common reed were 


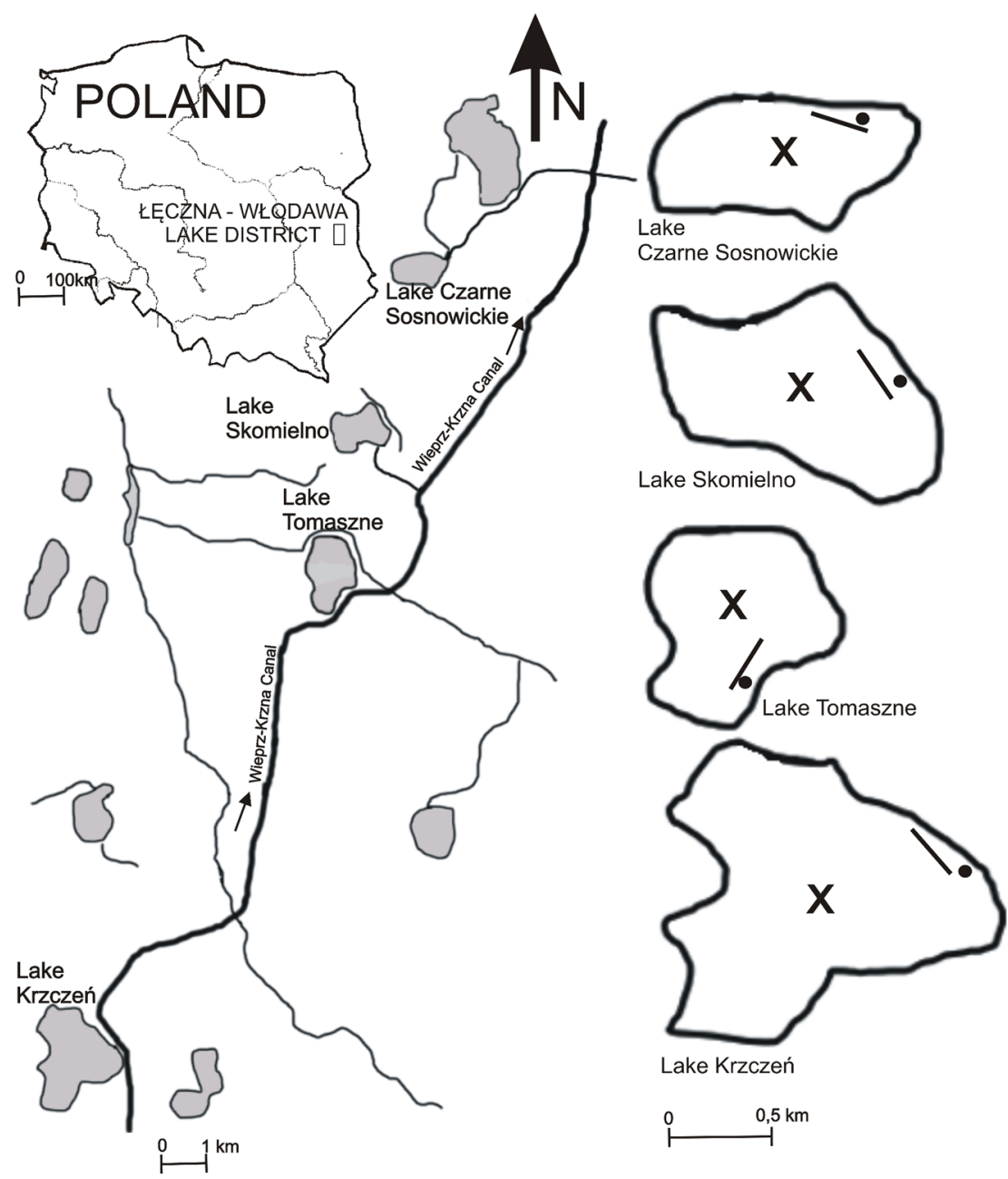

Fig. 1. Location of the lakes and sampling points. • - sampling point in littoral, $\mathrm{x}$ - sampling point in pelagial, - sampling point for fish collection

Table 1. Basic limnological characteristics of the studied lakes.

\begin{tabular}{|c|c|c|c|c|}
\hline & Skomielno & Czarne Sosn. & Tomaszne & Krzczeń \\
\hline Area (ha) & 75 & 38 & 95 & 174 \\
\hline Max. depth (m) & 3.5 & 15.6 & 3.1 & 5.2 \\
\hline SWAm. $(\mathrm{cm})^{\mathrm{a}}$ & $5-8$ & n.d. & $12-32$ & $4-28$ \\
\hline Frequency of WLFs ${ }^{\mathrm{a}}$ & $0-1$ & n.d. & $1-2$ & $0-1$ \\
\hline TSI SD $+\mathrm{P}$ tot. + Chl-a & 51 & 65 & 67 & 80 \\
\hline Trophic status & Meso-eutrophic & Eutrophic & Eutrophic & Hypertrophic \\
\hline $\begin{array}{l}\text { Submerged macrophyte } \\
\text { cover ( } \% \text { of lake area) }\end{array}$ & $33^{\mathrm{b}}$ & $9^{c}$ & $39^{\mathrm{d}}$ & $28^{\mathrm{d}}$ \\
\hline $\begin{array}{l}\text { Emergent macrophyte cover } \\
\text { (\% of lake area) }\end{array}$ & $49^{\mathrm{b}}$ & $19^{\mathrm{c}}$ & $13^{\mathrm{e}}$ & $20^{\mathrm{e}}$ \\
\hline Use of the lake & $\begin{array}{l}\text { Private user special } \\
\text { angling site }\end{array}$ & No manager & $\begin{array}{l}\text { Private fish farm special } \\
\text { angling site }\end{array}$ & $\begin{array}{l}\text { Polish Angling } \\
\text { Association }\end{array}$ \\
\hline Fishery management & $\begin{array}{l}\text { Fish stocking, used by } \\
\text { anglers }\end{array}$ & $\begin{array}{l}\text { No fish stocking, used } \\
\text { by anglers }\end{array}$ & $\begin{array}{l}\text { Fish stocking, used by } \\
\text { anglers }\end{array}$ & $\begin{array}{l}\text { Fish stocking }{ }^{\mathrm{f}} \text {, used by } \\
\text { anglers }\end{array}$ \\
\hline
\end{tabular}

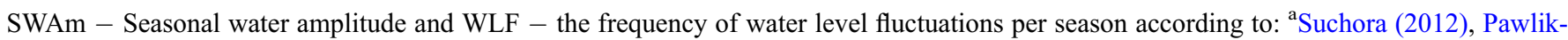
Skowrońska and Toporowska (2016), n.d. - no data. Macrophyte cover according to: ${ }^{\mathrm{b}}$ Sender (2012), ${ }^{\mathrm{c}}$ Sender (2016), ${ }^{\mathrm{d}} \mathrm{Mieczan}$ et al. (2016), ${ }^{e}$ approximate data obtained from the calculations based on satellite images, ${ }^{\mathrm{f}} \mathrm{http}: / / \mathrm{www}$. pzw.org.pl/naszewody/cms/6702/zarybienie. 
collected in April, July, and October 2012 in the standard sampling point located in littoral zone of eastern shore of Lakes Skomielno and Krzeń, north-eastern shore $\mathrm{t}$ of Lake Czarne Sosn., and south-eastern shore of Lake Tomaszne (Fig. 1). Location of the sampling points allowed minimization of differences of potential effects of wind and wave on epiphyton. Approximately $30 \mathrm{~cm}$ long segments of 3-4 reed stems per plant bed in the study lakes were collected randomly, a few centimeters below the water surface according to the method proposed by Karosienè and Kasperovičienè (2008). Algae were sampled by scraping (scalpel used in case of predominance of filamentous algae) or by brushing (toothbrush). Samples were collected using a container filled with tap water from a defined surface $\left(9.2-25.2 \mathrm{~cm}^{2}\right)$ of each $P$. australis stem to obtain one pooled sample from each lake per sampling occasion. The samples were preserved with Lugol's solution and then with a formalin-glycerin mixture. Algae were identified by using a light microscope and by referring to the following articles: Komárek and Fott (1983), Krammer and Lange-Bertalot (2004a; 2004b; 2007a; 2007b), Komárek and Anagnostidis (1999; 2000; 2005), and Komárek (2013). Diatoms were identified mostly up to the genus level according to Cox (1996). Algal systematics were based on Van den Hoek et al. (1995), and diatoms were classified up to the family level based on (2007a and b). Diatoms were subdivided to families, whereas Chlorophyta to groups Chlorophyceae and filamentous Chlorophyta. Up to 300 algal individuals were counted from random fields in a $1 \mathrm{~mL}$ Sedgewick-Rafter counting chamber (LeGresley and McDermott, 2010). Fragments of filamentous taxa equal to $100 \mu \mathrm{m}$ long and one colony of coccoid species were recognized as individuals. Epiphyton biomass was estimated by measuring the algal cell volume (Hillebrand et al., 1999). The biomass was expressed in milligram fresh weight per centimeter squared of reed stem branches. Taxa which share the total algal abundance or biomass of more than $10 \%$ were considered abundant. The Jaccard index, calculated for the total number of taxa identified in each lake, was used to compare the similarity of algal communities among the lakes. The Shannon-Wiener diversity index was also calculated for algal samples based on algal abundance, biovolume, and $\log$ transformed (log 10) values (Shannon and Weaver, 1949).

\subsection{Environmental background}

2.3.1 Physicochemical analyses of water and hydrological characteristics of the lakes

Water temperature, transparency (Secchi depth (SD)), pH, conductivity, and oxygen concentration were measured in situ in one sampling point in the pelagic and one sampling point in the littoral zone of the lakes (Fig. 1), in April, July, and October 2012. Water samples for analysis of chemical parameters were collected from the uppermost $(0-0.5 \mathrm{~m})$ layer of water in both the pelagic and littoral zones. $\mathrm{P}-\mathrm{PO}_{4}$ and $\mathrm{P}_{\text {tot. }}$ were determined by spectrophotometric method with ammonium molybdate (PN-C-04576, 2004; spectrophotometer SPECORD 40). N$\mathrm{NO}_{3}$ was determined by colorimetric method with brucine, whereas $\mathrm{N}-\mathrm{NH}_{4}$ by Nessler method (PN-C-04576-4, 1994). Due to brown-colour of water, $\mathrm{N}-\mathrm{NO}_{3}$ and $\mathrm{N}-\mathrm{NH}_{4}$ in samples from Lake Czarne Sosn. were analyzed according to DIN EN
ISO 29441, 2010 using a FIA Compact MLE. Total organic carbon (TOC) was determined using a PASTEL UV spectrophotometer. Total suspended solids (TSS) were determined after filtration of water on Whatman GF/C filters (PN-EN 872, 2007). All laboratory analyses were performed in duplicates. The molar ratios of DIN/DIP (dissolved inorganic phosphorus: $\mathrm{P}-\mathrm{PO}_{4}$ ) were determined after conversion of concentration of DIN and DIP to $\mu \mathrm{mol} \mathrm{L}^{-1}$ and dividing the obtained results. The Trophic State Indexes (based on water transparency - SD, $\mathrm{P}_{\text {tot. }}$, and chl-a concentrations) were calculated according to the method of Carlson (1977) for both the pelagic and littoral zones of the lakes. When SD value was down to the bottom, $\mathrm{TSI}_{\mathrm{SD}}$ was calculated based on the value of SD measured for pelagic zone.

Seasonal water amplitude (SWAm.) and the frequency of WLFs in Lakes Krzczeń, Tomaszne, and Skomielno were obtained from calculations based on watermark readings presented by Suchora (2012) and Pawlik-Skowrońska and Toporowska (2016) and were highest in Lakes Tomaszne and Krzczeń (Tab. 1). There are no such data for Lake Czarne Sosn. (Regional Management Office for Irrigation and Water Systems in Biała Podlaska, personal communication).

\subsubsection{Phytoplankton chl-a analyses}

From the littoral zone of each lake, $0.2-1 \mathrm{~L}$ of sample of water was collected to determine phytoplankton chl-a. According to the PN-ISO 10260 (2002), the water samples were filtered by $\mathrm{GF} / \mathrm{C}$ Whatman filters and were extracted for $5 \mathrm{~min}$ in $90 \%$ ethanol in water bath at $75^{\circ} \mathrm{C}$. After collecting the supernatants, chl-a was analyzed spectrophotometrically (Specord 40 Analytik Jena). Chl-a was analyzed in duplicates.

\subsubsection{Collection and analyses of potential grazers (littoral crustaceans and fish)}

Littoral crustaceans (Cladocera and Copepoda) were collected using a $5 \mathrm{~L}$ Ruttner sampler during the midday hours (between 10 a.m. and 3 p.m). To reduce the heterogeneity in the distribution of crustaceans and sampling variability, duplicate samples were collected and pooled. Samples were sieved through a mesh net $(40 \mu \mathrm{m})$ and fixed in formalin-glycerin solution. The crustaceans were classified and counted using the Sedgewick-Rafter chamber to calculate the abundance expressed as number of individuals per one liter sample. Only the abundance of potential algal grazers was used for statistical analyses.

Fish were collected once a season in the littoral zone of the lakes using two multi-mesh gillnets $(6.25-75.0 \mathrm{~mm})$ set for $12 \mathrm{~h}$, from 6 p.m. to 6 a.m. (Appelberg, 2000; de Normalisation, 2005). All fish caught were determined up to species level and their total length (TL, in $\mathrm{cm}$ ) was measured. Fish were divided into two classes based on size: TL $<6 \mathrm{~cm}$ and $\mathrm{TL}>6 \mathrm{~cm}$ to identify the abundance of small fish being able to graze algae. For analyses, we used both the abundance of small fish (TL $<6 \mathrm{~cm})$ from all species collected and the abundance of larger fish but only species known as algivorous. All fish data obtained were converted to catch per unit effort (CPUE) and presented as the number of fish individuals caught in one net after $12 \mathrm{~h}$ of fishing (ind. net ${ }^{-1}$ $\left.12 \mathrm{~h}^{-1}\right)$. 


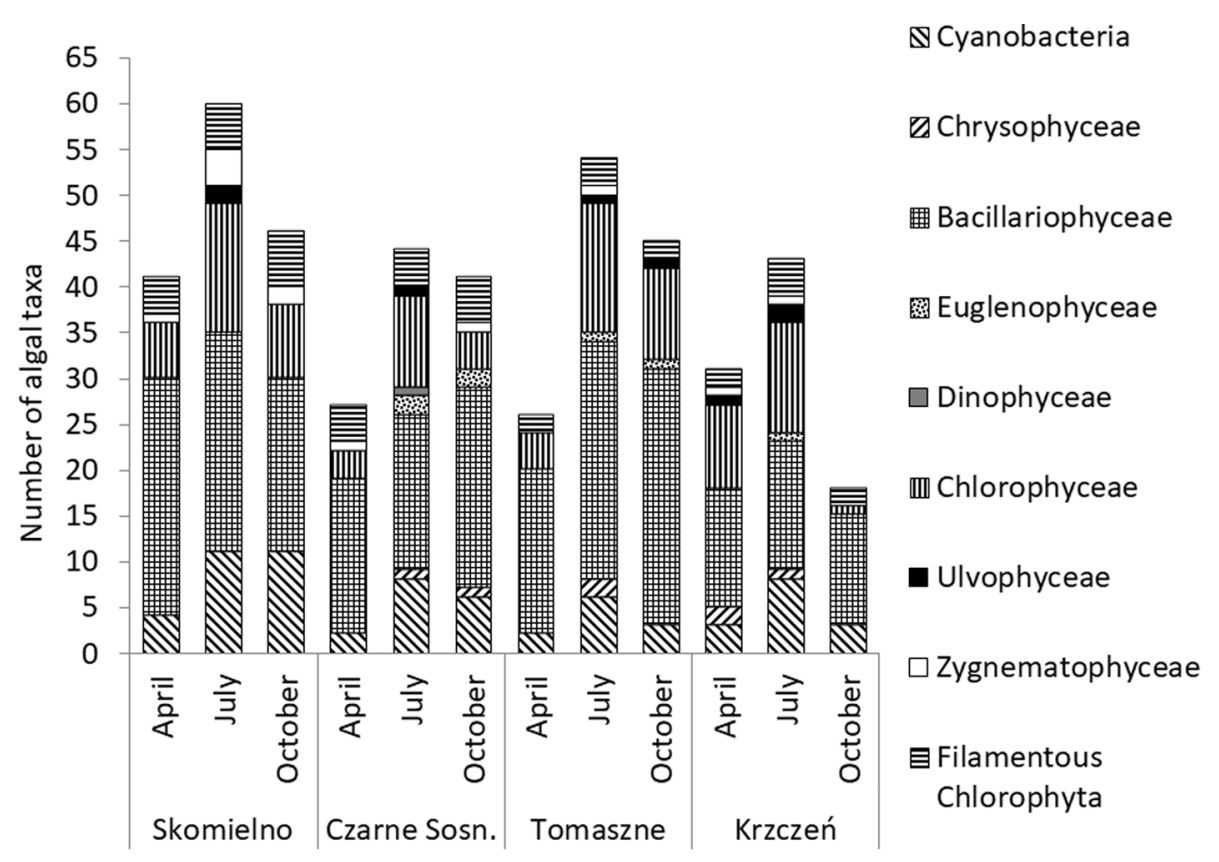

Fig. 2. Number of taxa of epiphytic algae in the studied lakes. The total number of taxa was equal to 94, 89, 75 and 64 in Lakes Skomielno, Tomaszne, Czarne Sosn. and Krzczeń, respectively.

\subsection{Statistical analyses}

Differences in the physicochemical parameters of waters in the littoral zone of the lakes ( 15 environmental variables: water temperature, transparency, $\mathrm{pH}$, conductivity, concentrations of oxygen, $\mathrm{N}-\mathrm{NH}_{4}, \mathrm{~N}-\mathrm{NO}_{3}, \mathrm{P}-\mathrm{PO}_{4}, \mathrm{P}_{\text {tot }}$. and phytoplankton chla, ratio of DIN/DIP, TSS,TOC, SWAm., frequency of WLFs), and the abundance of potential algal grazers (crustaceans and fish) among lakes and seasons were analyzed using a series of two-way analysis of variance (ANOVA, factor 1: lake, factor 2: season, and factor 3: interaction of lake versus season). All analyses and statistical tests described above were performed using the Statsoft Statistica package for Windows.

To describe the relationships between the abundance of taxonomic groups of epiphytic algae and environmental variables, we used an ordination technique. To measure and illustrate gradients of algal communities detrended correspondence analysis (DCA), the indirect multivariate method, was used. Due to the length of the gradient with a range $<3$ standard deviations, we used redundancy analysis (RDA) to explore the relationships between the abundance of taxonomic groups of algae and environmental variables. Before performing analysis, we evaluated correlation coefficients among environmental variables and employed forward selection to detect and remove variables that were highly correlated. The final set of variables included in the analysis were: water temperature, transparency, $\mathrm{pH}$, conductivity, concentrations of oxygen, $\mathrm{N}-\mathrm{NH}_{4}, \mathrm{~N}-\mathrm{NO}_{3}$, $\mathrm{P}-\mathrm{PO}_{4}, \mathrm{P}_{\text {tot. }}$, phytoplankton chl-a, DIN/DIP ratio, TOC, TSS, frequency of WLFs, abundance of fish and crustaceans species. RDA was based on normalized, log transformed data. A Monte Carlo analysis with 499 permutations was used to determine the most important variables. The ordination analyses were performed in CANOCO 4.5 software for Windows (ter Braak and Šmilauer, 2002).
Table 2. The Jaccard index of similarity of epiphytic algal communities inhabiting common reed in the studied lakes.

\begin{tabular}{llll}
\hline & Skomielno & Tomaszne & CzarneSosn. \\
\hline Krzczeń & 0.29 & 0.34 & 0.32 \\
CzarneSosn. & 0.35 & 0.37 & - \\
Tomaszne & 0.34 & - & - \\
\hline
\end{tabular}

\section{Results}

\subsection{Structure of epiphytic algal communities}

The qualitative (Fig. 2) and quantitative (Fig. 3) structure of epiphytic algal communities on common reed varied among the lakes and seasons. In all sampling occasions, algal taxa richness (Fig. 2) was the highest in the meso-eutrophic Lake Skomielno and the lowest in the hypertrophic Lake Krzczeń. In all the study lakes, the highest number of algal taxa was noted in July (from 43 to 60 taxa). Bacillariophyceae followed by Chlorophyceae and Cyanobacteria dominated in the total number of taxa (Fig. 2). Diatoms reached the highest taxa richness in the eutrophic Lake Tomaszne. In all the study lakes, diatoms achieved the highest richness in April and October. The share of Chlorophyceae and Cyanobacteria was the highest in July and October. The highest share of Zygnematophyceae was observed in Lake Skomielno during summer (July), whereas the highest share of Euglenophyceae was observed in Lake Czarne Sosn. in July and October. Values for the Jaccard index $(\mathrm{J})$ varied within a narrow range $(J=0.29$ 0.37 ) and indicated low species similarity of epiphytic algal assemblages among the lakes (Tab. 2). 

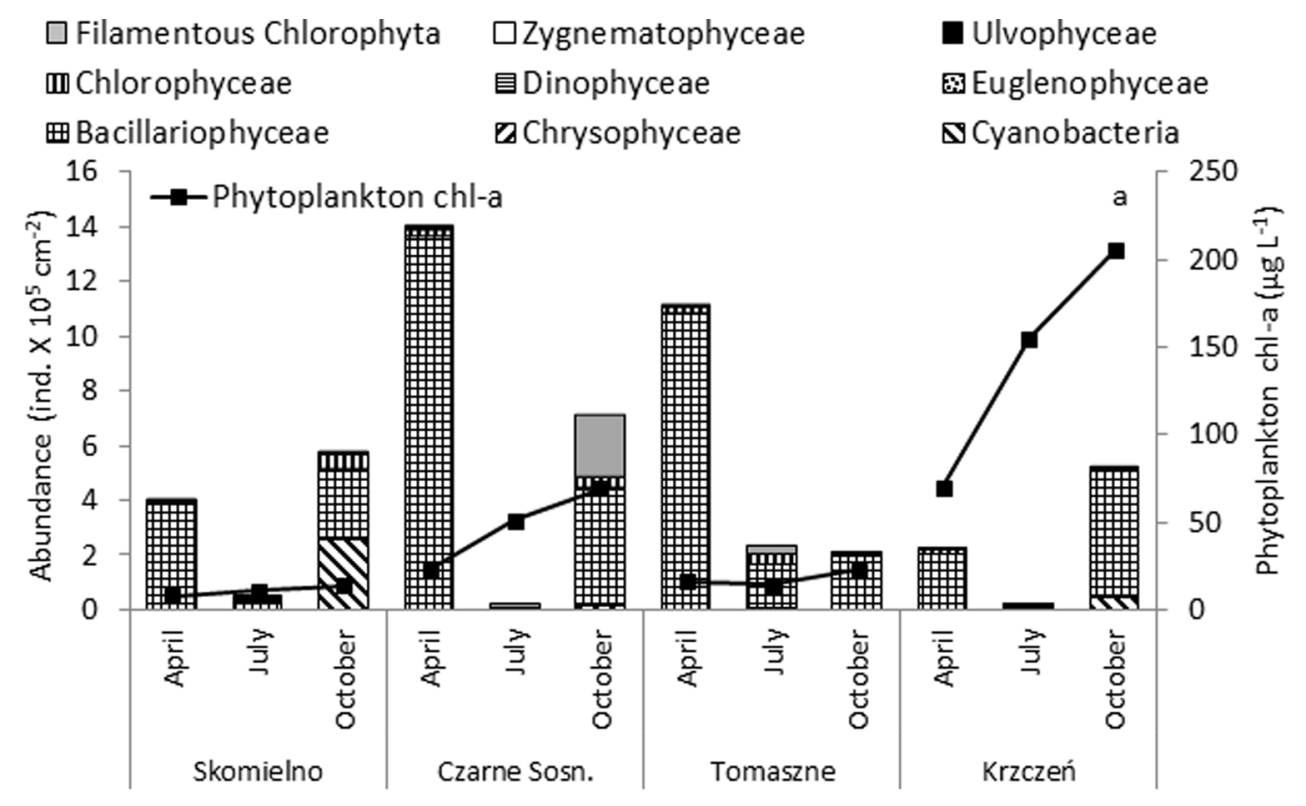

\section{- Ulvophyceae Bonglenophyceae \\ $\triangle$ Cyanobacteria}

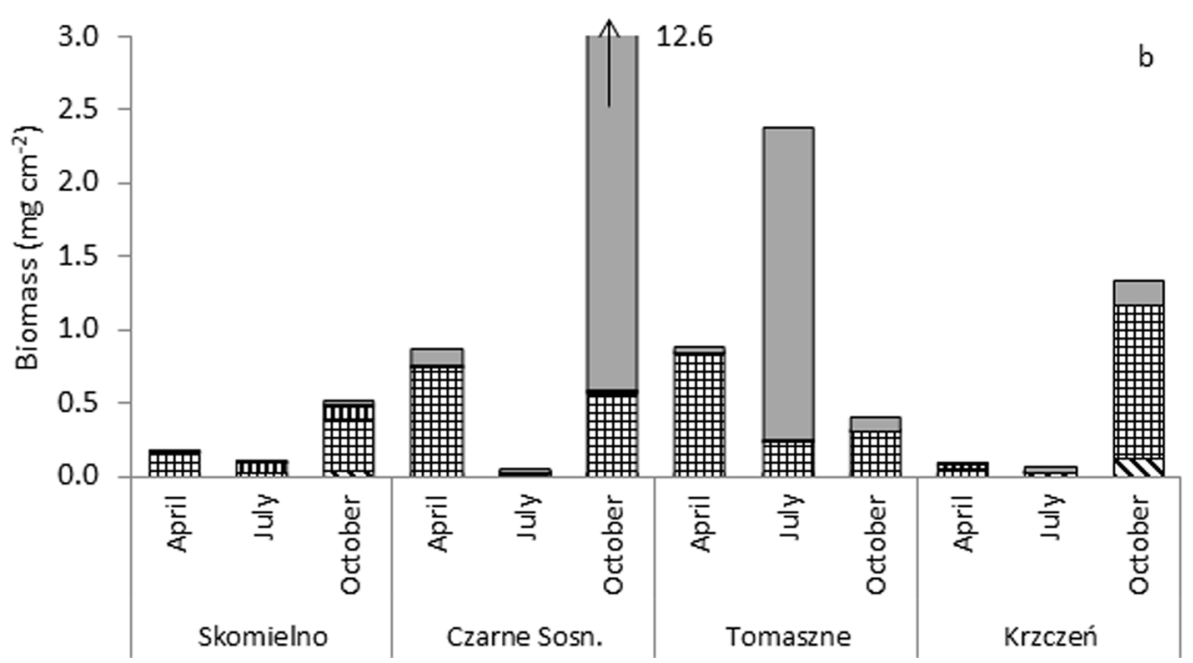

Fig. 3. Abundance of epiphytic algae against the background of phytoplankton development (a) and epiphyton biomass (b) in the studied lakes.

The abundance and biomass of epiphytic algae (Fig. 3a, b) reached higher values in Lakes Tomaszne and Czarne Sosn. in comparison with Lakes Skomielno and Krzczeń. In general, Bacillariophyceae dominated in all seasons and all the study lakes (63-97\% of the total algal abundance). Cyanobacteria had a high share $(44 \%)$ in Lake Skomielno in October, whereas in Lakes Czarne Sosn. and Krzczeń, in addition to diatoms, Chlorophyceae (19 and 25\%, respectively) and Cyanobacteria (12 and 25\%) were abundant in July (Fig. 3a). The total algal biomass (Fig. 3b) was the highest in October and April (except Lake Tomaszne) and consisted primarily of diatoms. In July, Bacillariophyceae biomass decreased. In Lake Skomielno, diatoms were replaced by coccoid Chlorophyceae $(69 \%)$, whereas in other water bodies, they were replaced by filamentous Chlorophyta (57-92\%, in summer and/or autumn). In Lakes Skomielno, Czarne Sosn., and Krzczeń, algal biomass and phytoplankton chl-a showed similar seasonal variability $(r=0.76-0.99 ; P<0.05)$. In the hypertrophic Lake Krzczeń, during strong algal bloom observed from spring to autumn (70-204 $\mu \mathrm{g}$ of chl-a $\mathrm{L}^{-1}$, Fig. 3a), epiphyton biomass was lower than in the two other eutrophic lakes (Fig. 3b).

The composition of abundance and biomass of diatoms, a dominating group of algae, differed among the lakes and (except Lake Czarne Sosn.) seasons (Fig. 4). In all the study lakes, in April, one of the most abundant group within diatoms was small pennate Achnanthaceae (Fig. 4a) with Achnanthidium minutissimum (Tab. 3), which was also abundant in Lakes Tomaszne and Czarne Sosn. in October. Table 3 presents algal dominants and their seasonal occurrence.

Despite differences in species richness and composition of epiphyton among the lakes, algal diversity (expressed by the Shannon-Wiener index, H) based on algal abundance was similar in all lakes $(H=0.9-1.2, n=3)$. The average diversity index based on algal biomass in the meso-eutrophic Lake Skomielno was twice as high $(H=1.2, n=3)$ as in the other, more eutrophicated lakes $(H=0.6-0.7, n=3)$. However, the difference was not significant $(P>0.05)$. 

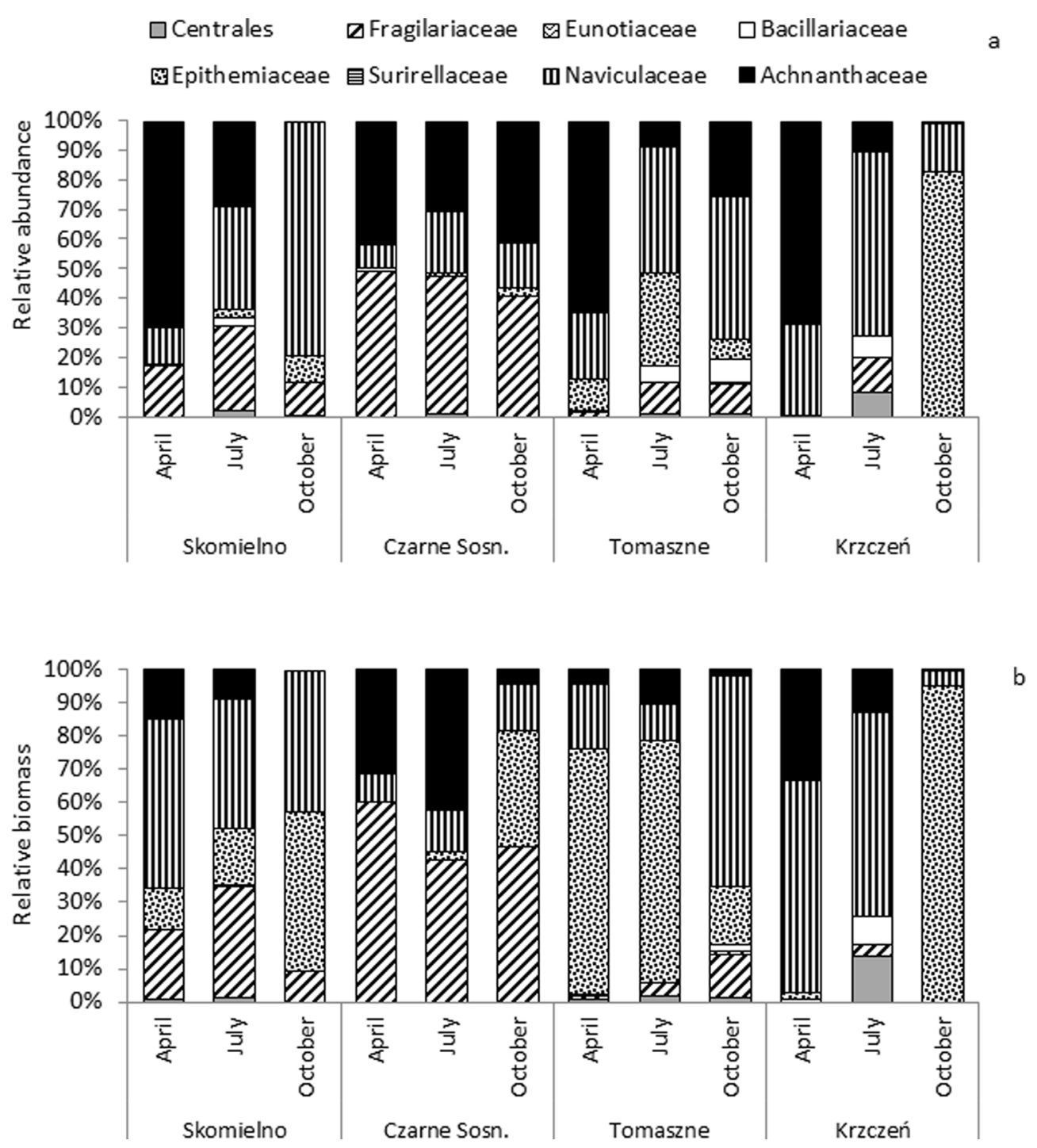

Fig. 4. Structure of abundance (a) and biomass (b) of epiphytic diatoms in the studied lakes.

\subsection{Environmental background}

3.2.1 Physicochemical parameters of water and hydrological characteristics of the lakes

High variability of some physicochemical, hydrological, and biological parameters among the study lakes and seasons was found (Tabs. 1 and 4, Supplementary Material, App. 1). Among physicochemical factors, water transparency $(F=46.680$, d.f. $=12, P<0.001)$, concentrations of TSS $(F=119.164, \quad$ d.f. $=12, \quad P=0.006), \quad$ total phosphorus $(F=6.842, \quad$ d.f. $=12, \quad P=0.002), \quad$ phytoplankton chl-a $(F=8.551$, d.f. $=12, P=0.007)$, and conductivity $(F=5.437$, d.f. $=20, P=0.014$ ) showed significant differences among the lakes. Some differences among the seasons were also observed (App. 1). Water temperature was the most differential parameter among seasons, whereas transparency, and the concentrations of TSS and phytoplankton chl-a were the most differential factors among lakes and seasons. In general, the highest water transparency (Tab. 4) was observed in the mesoeutrophic Lake Skomielno (TSI $=44-62)$ and in the eutrophic
Lake Czarne Sosn., where the lowest concentrations of TSS (mean values: 3.00 and $6.39 \mathrm{mg} \mathrm{L}^{-1}$, respectively) and phytoplankton chl-a (10.9 and $17.8 \mu \mathrm{g} \mathrm{L}^{-1}$, respectively) were observed. In all the study lakes, waters in littoral zones were alkaline, well oxygenated, and nutrient-rich, with similar temperature conditions (Tab. 4). Man-made WLFs were the most frequent in Lake Tomaszne (1-2 per season), whereas in Lakes Skomielno and Krzczeń, they occurred once a season (Tab. 1): in spring and autumn (Suchora, 2012; Pawlik-Skowrońska and Toporowska, 2016).

\subsubsection{Crustacean communities}

Among littoral crustaceans, grazers' species achieved low densities (Fig. 5a), which ranged from below 1 to 10 ind. $\mathrm{L}^{-1}$. ANOVA did not reveal differences in their abundance among the lakes $(F=1.354$, d.f. $=3, P=0.324)$; however, some differences between lakes and seasons were found (App. 1). Crustaceans showed a very uneven dominance; five species were found to be dominant in the studied lakes, including 
Table 3. The dominant algal taxa (of relative frequency in the total abundance/biomass higher than 10\%) on common reed in particular lakes and months. A - April, J - July, O - October. "-" contribution $<10 \%$.

\begin{tabular}{|c|c|c|c|c|}
\hline Algal taxa & Skomielno & Tomaszne & Czarne Sosn. & Krzczeń \\
\hline \multicolumn{5}{|l|}{ Cyanobacteria } \\
\hline Aphanothece sp. & $36.9 /-\%(\mathrm{O})$ & & & \\
\hline Microcystis wesenbergii & & & & $-/ 13.0 \%(\mathrm{~J})$ \\
\hline \multicolumn{5}{|l|}{ Bacillariophyceae } \\
\hline \multicolumn{5}{|l|}{ Achnantchaceae } \\
\hline & $60.0 / 11.7(\mathrm{~A})$ & $51.1 /-\%(\mathrm{~A})$ & $32.3 / 6.2 \%(\mathrm{~A})$ & $61.8 / 16.3 \%(\mathrm{~A})$ \\
\hline Achnanthidium minutissimum & $15.6 /-(\mathrm{J})$ & $22.3 /(\mathrm{O})$ & $24.7 /-\%(\mathrm{O})$ & \\
\hline Cocconeis pediculus & & & $-/ 20.3 \%(\mathrm{~J})$ & \\
\hline \multicolumn{5}{|l|}{ Epithemiaceae } \\
\hline \multirow{2}{*}{ Epithemia adnata } & & $-/ 63.6 \%(\mathrm{~A})$ & & $-/ 17.7 \%(\mathrm{O})$ \\
\hline & & $10.8 / 5.4 \%(\mathrm{~J})$ & & \\
\hline \multirow[t]{2}{*}{ E. sorex } & $-/ 11.2 \%(\mathrm{~A})$ & $10.1 /-(\mathrm{J})$ & & $65.3 / 56.9 \%(\mathrm{O})$ \\
\hline & $-/ 12.9 \%(\mathrm{O})$ & & & \\
\hline Rhopallodia cf. gibba & $-/ 15.0 \%(\mathrm{O})$ & & & \\
\hline \multicolumn{5}{|l|}{ Fragilariaceae } \\
\hline Fragilaria sp. & & & $46.5 / 33.2 \%(\mathrm{~A})$ & \\
\hline Staurosira cf. construens & $13.1 /-\%(J)$ & & $13.7 /-\%(\mathrm{O})$ & \\
\hline Synedra ulna & & & $-/ 17.7 \%(\mathrm{~A})$ & \\
\hline \multicolumn{5}{|l|}{ Naviculaceae } \\
\hline Cymbella spp. & $-/ 26.9 \%(\mathrm{~A})$ & $-/ 10.5 \%(\mathrm{O})$ & & \\
\hline cf. Encyonopsis microcephala & $20.2 / 10.7 \%(\mathrm{O})$ & & & \\
\hline \multirow[t]{2}{*}{ Gomphonema spp. (cf. olivaceum + parvulum) } & $-/ 12.9 \%(\mathrm{~A})$ & $16.6 / 12.3 \%(\mathrm{~A})$ & & $26.7 / 35.8 \%(\mathrm{~A})$ \\
\hline & & $24.4 / 22.4 \%(\mathrm{O})$ & & \\
\hline \multicolumn{5}{|l|}{ Chlorophyceae } \\
\hline Duceriella chodatii & $-/ 10.9 \%(J)$ & & & \\
\hline Pandorina morum & & & & $-/ 24.5 \%(\mathrm{~A})$ \\
\hline Pediastrum boryanum & $-/ 54.8 \%(\mathrm{~J})$ & & & \\
\hline \multicolumn{5}{|l|}{ Filamentous Chlorophyta } \\
\hline \multicolumn{2}{|l|}{ Gongrosira cf. debaryana } & & $39.9 / 52.9 \%(\mathrm{~J})$ & $5.6 / 64.7 \%(\mathrm{~J})$ \\
\hline \multirow{2}{*}{\multicolumn{2}{|c|}{ Oedogonium spp. }} & $-/ 15.1 \%(J)$ & & $-/ 12.5 \%(\mathrm{O})$ \\
\hline & & $-/ 13.9 \%(\mathrm{~A})$ & & \\
\hline \multicolumn{2}{|l|}{ Protoderma sp. } & & $-/ 13.2 \%(\mathrm{~A})$ & \\
\hline \multicolumn{2}{|l|}{ Spirogyra spp. } & $-/ 74.5 \%(J)$ & $27.6 / 95.4 \%(\mathrm{O})$ & \\
\hline
\end{tabular}

Acroperus harpae and Alonella nana during April and/or July; Alona quadrangularis, Alonella exigua, and Sida crystallina were found to be dominant during July and/or October.

\subsection{Fish communities}

Statistical analysis showed differences $(F=6.803$, d.f. $=3$, $P=0.014)$ in abundance of fish among the lakes and seasons (App. 1). The fish abundance (Fig. 5b) was the lowest (10 22CPUE) in Lake Skomielno and the highest (100-336CPUE) in Lake Krzczeń. In Lakes Skomielno, Tomaszne, and Czarne Sosn., the dominant species was roach (Rutilus rutilus) with average total length equal to $8.9 \mathrm{~cm} ; 11.7 \mathrm{~cm}$ and $9.8 \mathrm{~cm}$, respectively. In Lake Skomielno, only single individuals of roach with the total length higher than $6 \mathrm{~cm}$ were noted. In Lake Krzczeń, fish community was more diverse and small individuals (TL $<6 \mathrm{~cm}$ ) of bleak (Alburnus alburnus), rudd (Scardinius erythrophthalmus), and perch (Perca fluviatilis), reached seasonally high densities. The fish abundance and structure were similar in the other studied lakes (Fig. 5b).

\subsection{Relationship among epiphytic algal assemblages, physicochemical variables, and potential algal grazers}

Redundancy analysis (RDA, Fig. 6) revealed that the four axes accounted respectively for $21.7,19.6,17.3$, and $16.0 \%$ of variability in composition of epiphytic algae. Axis 1 showed a strongly positive correlation with water transparency and frequency of WLFs showed a negative correlation with abundance of three fish species: A. alburnus, $R$. rutillus, and $S$. erythrophthalmus (Tab. 5). Axis 2 showed positive correlation with water temperature and negative correlation with the DIN/DIP ratio and $\mathrm{N}-\mathrm{NO}_{3}$ concentration. Axis 3 showed negative correlation with $\mathrm{P}_{\text {tot. }}$, aforementioned three fish species, and phytoplankton chl-a, whereas axis 4 showed positive correlation with $\mathrm{P}-\mathrm{PO}_{4}$ concentration and abundance of crustaceans belonging to Pleuroxus and negative correlation with conductivity and frequency of WLFs. RDA (Fig. 6) showed the highest significance of frequency of WLFs $(\lambda=0.16 ; F=1.85 ; P=0.036)$; however, rudd $(S$. erythroph thalmus $)$ seemed to be also important $(\lambda=0.12 ; F=3.12$; $P=0.092$ ) for algal composition. Frequent WLFs increasing 
M. Toporowska et al.: Knowl. Manag. Aquat. Ecosyst. 2018, 419, 18

Table 4. Basic limnologicaldata of littoral sampling points in the studied lakes (mean $\pm \mathrm{SD}, n=6$ ).

\begin{tabular}{|c|c|c|c|c|}
\hline Parameters & Skomielno & CzarneSosn. & Tomaszne & Krzczeń \\
\hline Depth (m) & $1.08 \pm 0.11$ & $0.82 \pm 0.43$ & $1.08 \pm 0.32$ & $1.47 \pm 0.1$ \\
\hline Transparency $(\mathrm{m})$ & Down to the bottom ${ }^{a}$ & $0.40-$ down to the bottom ${ }^{b}$ & $0.72 \pm 0.19$ & $0.43 \pm 0.20$ \\
\hline Water temperature $\left({ }^{\circ} \mathrm{C}\right)$ & $14.9 \pm 5.5$ & $15.1 \pm 4.9$ & $15.0 \pm 5.0$ & $14.5 \pm 4.6$ \\
\hline $\mathrm{pH}$ & $8.3 \pm 0.1$ & $7.8 \pm 0.4$ & $8.5 \pm 0.3$ & $8.2 \pm 0.6$ \\
\hline Conductivity $\left(\mu \mathrm{S} \mathrm{cm}^{-1}\right)$ & $277 \pm 30$ & $317 \pm 27$ & $350 \pm 6$ & $279 \pm 45$ \\
\hline Oxygen $\left(\mathrm{mg} \mathrm{L}^{-1}\right)$ & $9.6 \pm 0.7$ & $7.7 \pm 0.6$ & $11.5 \pm 2.9$ & $9.0 \pm 3.1$ \\
\hline $\mathrm{N}-\mathrm{NH}_{4}\left(\mathrm{mg} \mathrm{L}^{-1}\right)$ & $0.113 \pm 0.22$ & $0.061 \pm 0.022$ & $0.085 \pm 0.025$ & $0.117 \pm 0.025$ \\
\hline $\mathrm{N}-\mathrm{NO}_{3}\left(\mathrm{mg} \mathrm{L}^{-1}\right)$ & $0.120 \pm 0.122$ & $0.143 \pm 0.069$ & $0.163 \pm 0.091$ & $0.152 \pm 0.067$ \\
\hline $\mathrm{P}-\mathrm{PO}_{4}\left(\mathrm{mg} \mathrm{L}^{-1}\right)$ & $0.039 \pm 0.023$ & $0.026 \pm 0.011$ & $0.013 \pm 0.011$ & $0.038 \pm 0.023$ \\
\hline DIN/DIP ratio ${ }^{c}$ & $27.5 \pm 36.6$ & $17.2 \pm 6.5$ & $59.4 \pm 37.5$ & $22.1 \pm 1.1$ \\
\hline P tot. $\left(\mathrm{mg} \mathrm{L}^{-1}\right)$ & $0.060 \pm 0.026$ & $0.072 \pm 0.22$ & $0.085 \pm 0.077$ & $0.244 \pm 0.016$ \\
\hline TOC $\left(\mathrm{mg} \mathrm{L}^{-1}\right)$ & $4.73 \pm 0.26$ & $18.13 \pm 1.96$ & $4.32 \pm 0.37$ & $5.73 \pm 0.63$ \\
\hline $\mathrm{TSS}\left(\mathrm{mg} \mathrm{L}^{-1}\right)$ & $3.00 \pm 2.65$ & $6.39 \pm 1.89$ & $9.9 \pm 1.14$ & $31.58 \pm 23.00$ \\
\hline Phytoplankton chlorophyll-a $\left(\mu \mathrm{g} \mathrm{L}^{-1}\right)$ & $10.9 \pm 3.1$ & $17.8 \pm 4.4$ & $48.0 \pm 23$ & $143.1 \pm 68$ \\
\hline $\mathrm{TSI}_{\mathrm{SD}}$ & 46 & 70 & 70 & 73 \\
\hline TSI $_{\text {Ptot. }}$ & 65 & 68 & 67 & 83 \\
\hline $\mathrm{TSI}_{\mathrm{Chl}-\mathrm{a}}$ & 54 & 57 & 69 & 80 \\
\hline TSI $\mathrm{SD}+\mathrm{P}$ tot. + Chl-a & 55 & 65 & 69 & 79 \\
\hline Trophic status & Meso-eutrophic & Eutrophic & Eutrophic & Hypertrophic \\
\hline
\end{tabular}

${ }^{\mathrm{a}} \mathrm{Up}$ to $1.50 \mathrm{~m}$.

${ }^{\mathrm{b}} \mathrm{Up}$ to $1.30 \mathrm{~m}$, except spring $-0.4 \mathrm{~m}$.

${ }^{\mathrm{c}}$ Molar ratio of dissolved inorganic nitrogen and phosphorus.

SWAm. showed positive correlation with abundance of Epithemiaceae and Naviculaceae (Fig. 6a). The higher abundance of rudd, roach, and bleak correlated positively with small diatoms belonging to Achnanthaceae and negatively with the abundance of larger taxa belonging to Fragilariaceae, Centrales, and Cyanobacteria. Higher water transparency correlated positively with abundance of Cyanobacteria, Chlorophyceae, and Fragilariaceae. Phytoplankton chl-a correlated positively with Naviculaceae and Epithemiaceae, which were abundant in eutrophic lakes affected by water blooms and negatively with Zygnematophyceae, Centrales and Fragilariaceae, which were most abundant in less eutrophic water bodies (Tab. 3, Figs. 3 and 4). The increasing DIN/DIP ratio correlated positively with diatoms Naviculaceae and negatively with Euglenophyceae, which, together with Dinophyceae, correlated positively with TOC. $\mathrm{N}-\mathrm{NO}_{3}$ and $\mathrm{P}_{\text {tot. }}$ correlated with Achnathaceae and Surirellaceae abundance. The RDA biplots of environmental variables and samples (Fig. 6b) showed that sites could be divided into two groups: one of them was composed of summer samples and was characterized by higher water temperature, concentration of $\mathrm{P}-\mathrm{PO}_{4}$ and TOC, and abundance of perch and Sida. The second and the most heterogeneous group was composed of spring and autumn samples and characterized mostly by more frequent WLFs, higher DIN/DIP ratio, and $\mathrm{N}-\mathrm{NO}_{3}$ concentration. Autumn samples from Lakes Skomielno and Czarne Sosn. were separated from other sites primarily because of high water transparency.

\section{Discussion}

This is the first report on a complex field study concerning the species richness, diversity, and composition of abundance and biomass of epiphytic algae on the same macrophyte substratum in lakes differing among others in water-level management, trophic conditions, and structure of potential algal grazers: littoral crustaceans and fish. Some algal species may show substrate specificity (Cattaneo et al., 1998; Toporowska et al., 2008) caused, for example, by allelopathic activity of aquatic plants (Erhard and Gross, 2006). Therefore, it seems that our comparative study of epiphyton on the same species of macrophyte $P$. australis reveals the impact of environmental factors other than host plant more clearly.

Our most important finding in this study was that man-made WLFs, grazer-mediated top-down and nutrient-ratio- and lightmediated bottom-up forces may play a key role in controlling the species richness, abundance, and biomass of epiphytic algae on common reed in the studied shallow lakes. Our results suggest that lakes with intermediate light conditions and fish abundance have the highest potential for growth of epiphytic algae on this kind of substratum. In addition to various diatoms, filamentous Chlorophyta found better conditions for the development in the eutrophic reservoirs; however, they also developed abundantly in a hypertrophic lake (Laugaste and Reunanen, 2005). Our results also may suggest that no positive linear relationships occur between epiphyton biomass and lake trophic status, which agrees with the studies performed in some Swedish and Antarctic lakes, however, lacking fish and other potential algal grazers (Hansson, 1992), and with an experimental study by Liboriussen and Jeppesen (2006). Low values of Jaccard index of similarity of the epiphyton communities also indicated a substantial variation among the lakes, confirming that environmental conditions have a stronger impact on these communities than the specific architecture of the macrophyte substratum (Cattaneo et al., 1998; Messyasz and Kuczyńska-Kippen, 2006; Vadeboncoeur et al., 2006; Toporowska et al., 2008). In this study, the 

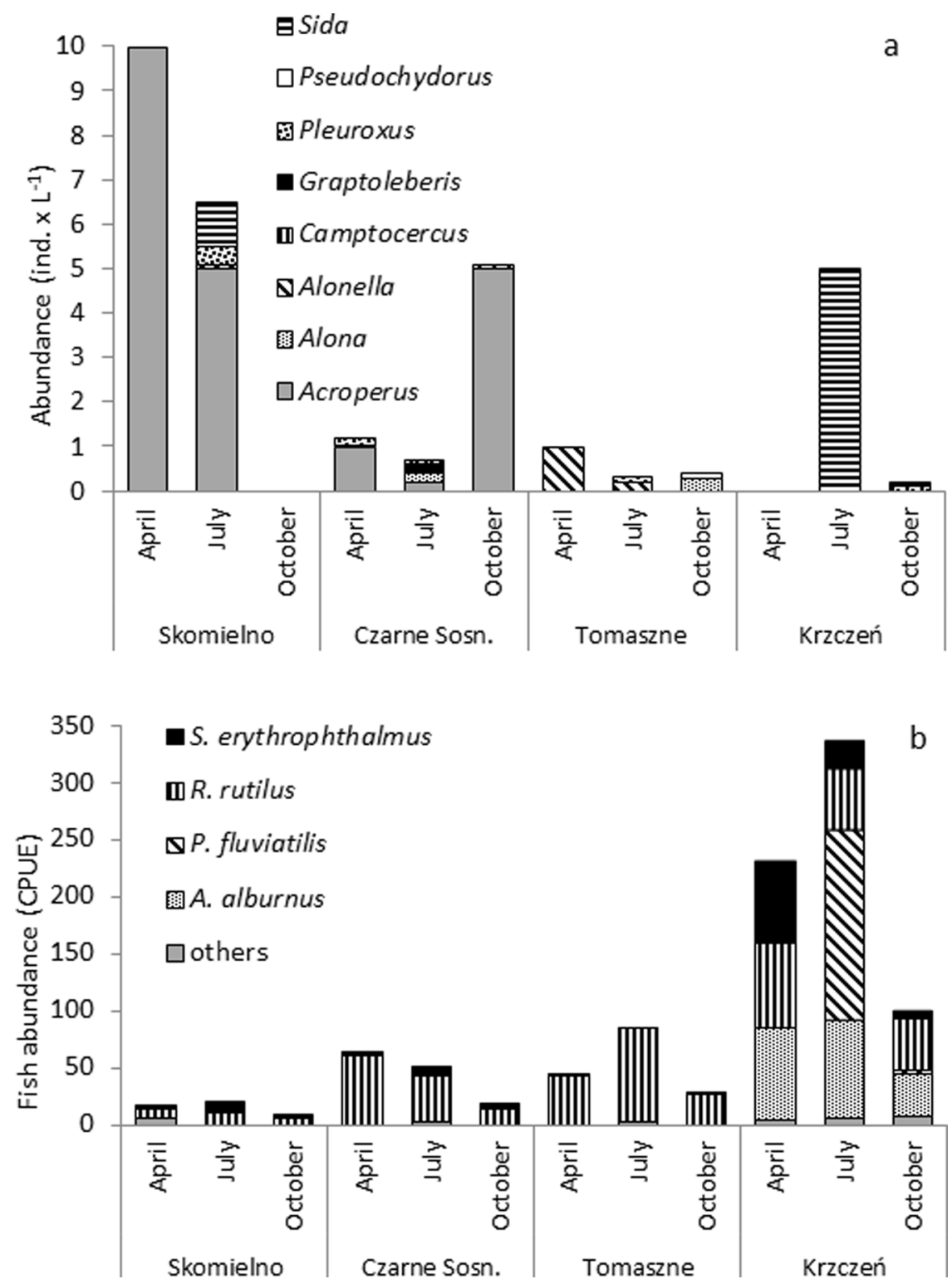

Fig. 5. Abundance and structure of potential algal grazers in the studied lakes: a - littoral crustaceans (Cladocera); b - fish.

observed decrease in algal species richness with increasing water trophy of the reservoirs is in agreement with field studies performed on phytoplankton (Reynolds, 2006). However, similar comparative field studies on epiphytic algae are scarce (Rodríguez et al., 2011). Despite some differences among the lakes in the number of species and algal abundance, we found that the diversity of algal assemblages based on abundance did not differ one from the other and was lower than, for example, in the meso-eutrophic Lake Gulbinas (Karosiene and Kasperovičiené, 2008). However, the diversity based on the algal biomass was found to be the highest in the least eutrophicated lake, which is in accordance with the results of a mesocosm experiment by Blanco et al. (2008). They revealed that species richness of epiphyton on the submerged Myriophyllum alterniflorum decreased significantly (from 15 to 32 taxa) with $\mathrm{N}$ and $\mathrm{P}$ enrichment.

RDA revealed that the higher frequency of WLFs causing changes in water amplitude was the most significant factor shaping algal composition in the studied lakes. Both natural and anthropogenic WLFs, especially their extent, frequency, and duration, are dominant forces controlling the functioning of shallow lakes (Leira and Cantonati, 2008). But effects of WLFs have not been studied equally for different groups of organisms, and there is a low interest on epiphytic algae. Rodríguez et al. (2011) showed that in humic shallow lakes in Argentina, the structure of the epiphytion assemblages on the emergent rush Schoenoplectus californicus changed in relation to WLFs, showing a major proportion of planktonic, metaphytic, and ticoplanktonic components during high water phases. Diatoms may be good indicators of some disturbance processes, including WLFs (Barbour et al., 1999; Pfeiffer et al., 2015). For example, the small pennate $A$. minutissimum is often the first species colonizing the substratum, and its relative abundance, lower than $25 \%$ of the total diatom abundance, is characteristic for undisturbed water bodies (Barbour et al., 1999). In the studied lakes, high abundance of 

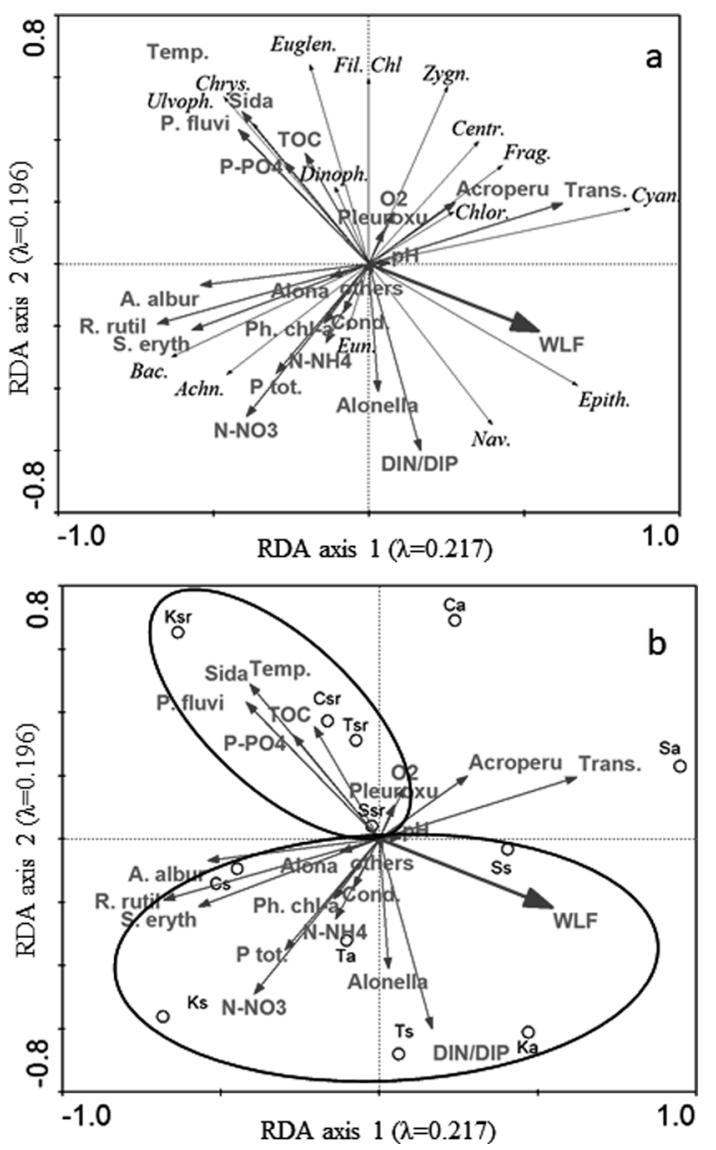

Fig. 6. Redundancy analysis (RDA) biplots of both abiotic and biotic environmental parameters and (a) particular taxonomic groups of epiphytic algae, including classes of diatoms, and (b) samples collected in particular lakes and seasons. Bolded arrow indicate significant variable (based on Monte Carlo permutation test), that influenced on epiphyton composition. Temp. - temperature, Trans. transparency, Cond. - conductivity, Ph. chl-a - phytoplankton chl-a, $\mathrm{O}_{2}$ - oxygen, $\mathrm{N}-\mathrm{NH}_{4}-$ ammonium nitrogen, $\mathrm{N}-\mathrm{NO}_{3}$ - nitrate nitrogen, DIN/DIP - ratio of dissolved inorganic nitrogen to dissolved inorganic phosphorus, TOC - total organic carbon, WLF the frequency of water level fluctuations; Centr. - Centrales, Frag. Fragilariaceae, Eun. - Eunotiaceae, Bac. - Bacillariaceae, Epith. Epithemiaceae, Sur. - Surirellaceae, Nav. - Naviculaceae, Achn. Achnanthaceae, Cyan. - Cyanobacteria, Chrys. - Chrysophyceae, Euglen. - Euglenophyceae, Dinoph. - Dinophyceae, Chlor. Chlorophyceae, Ulvoph. - Ulvophyceae, Zygn. - Zygnematophyceae, Fil. Chlor. - Filamentous Chlorophyta, littoral cladocerans: Acroperus - Acroperus, Alona - Alona, Alonella -Alonella, Graptole - Graptoleberis, Pleuroxu - Pleuroxus, Pseudoch Pseudochydorus, Sida - Sida; fish: A. albur - Alburnus alburnus, P. fluvi - Perca fluviatilis, R. rutil - Rutilus rutilus, S. eryth Scardinius erythrophthalmus; samples (examples): S - Skomielno, C - Czarne Sosn, T - Tomaszne, K - Krzczeń, s - spring (April), sr summer (July), a - autumn (October).

A. minutissimum was observed primarily during spring (32.3$61.8 \%$ of the total algal abundance), at the beginning of the vegetative season and shortly after the water inputs. However, nearly $25 \%$ share of $A$. minutissimum in Lakes Tomaszne and Czarne Sosn. during autumn indicate some lake disturbance,
Table 5. Redundancy analysis: inter-set correlation of environmental variables with axes of RDA for the studied samples. High correlation values are bolded.

\begin{tabular}{|c|c|c|c|c|}
\hline Variables & AX1 & AX2 & AX3 & AX4 \\
\hline \multicolumn{5}{|c|}{ Physicochemical and hydrological parameters } \\
\hline Trans. & 0.63 & 0.19 & 0.03 & 0.37 \\
\hline Temp. & -0.40 & $\mathbf{0 . 5 0}$ & -0.11 & 0.05 \\
\hline $\mathrm{pH}$ & 0.07 & 0.01 & -0.03 & -0.16 \\
\hline Cond. & -0.08 & -0.15 & 0.34 & -0.74 \\
\hline $\mathrm{N}-\mathrm{NH} 4$ & -0.14 & -0.25 & -0.23 & 0.26 \\
\hline $\mathrm{N}-\mathrm{NO} 3$ & -0.40 & -0.48 & 0.14 & 0.10 \\
\hline P-PO4 & -0.27 & 0.33 & -0.30 & 0.57 \\
\hline P tot. & -0.31 & -0.35 & -0.61 & 0.06 \\
\hline DIN/DIP & 0.16 & -0.60 & 0.34 & -0.29 \\
\hline $\mathrm{O} 2$ & 0.09 & 0.17 & 0.23 & -0.17 \\
\hline TOC & -0.20 & 0.36 & 0.06 & 0.18 \\
\hline TSS & 0.04 & -0.25 & -0.50 & -0.08 \\
\hline Ph. chl-a & -0.15 & -0.19 & -0.47 & -0.14 \\
\hline SWAm. & 0.20 & -0.50 & 0.07 & -0.51 \\
\hline WLF & 0.55 & -0.22 & 0.36 & -0.58 \\
\hline \multicolumn{5}{|l|}{ Fish } \\
\hline A. albur & -0.55 & -0.07 & -0.59 & 0.03 \\
\hline P. fluvi & -0.41 & 0.43 & -0.24 & 0.14 \\
\hline R. rutil & -0.68 & -0.19 & -0.08 & -0.20 \\
\hline S. eryth & -0.58 & -0.21 & -0.54 & -0.01 \\
\hline Others & 0.01 & -0.04 & -0.61 & 0.11 \\
\hline \multicolumn{5}{|l|}{ Crustaceans } \\
\hline Acroperu & 0.28 & 0.20 & 0.26 & 0.22 \\
\hline Alona & -0.12 & -0.04 & -0.00 & -0.36 \\
\hline Alonella & 0.03 & -0.41 & 0.32 & -0.22 \\
\hline Pleuroxu & 0.05 & 0.11 & 0.28 & 0.51 \\
\hline Sida & -0.41 & 0.44 & -0.22 & 0.22 \\
\hline
\end{tabular}

probably WLFs. Diatoms are also frequently used as bioindicators of ecological status of aquatic environments (Round, 1991; Hofmann, 1994). Some of the most abundant diatoms found on P. australis in the studied lakes are indicators of meso-eutrophic (Staurosira construens) and oxygensaturated waters (A. minutissimum, S. construens; van den Hoek et al., 1995). Most of the abundantly occurring epiphytic diatoms prefer slightly alkaline waters. Epithemia adnata and E. sorex are alkalibiontic organisms (van den Hoek et al., 1995).

Grazing pressure may be very important biotic factor shaping epiphyton assemblages (Abe et al., 2007; Guariento et al., 2010; Tarkowska-Kukuryk, 2013). In the studied lakes, the pressure from fish grazing (with $S$. erythrophthalmus as the most significant species) could affect epiphytic algae, particularly in Lake Krzczen, with the highest fish abundance. An experimental study (Abe et al., 2007) showed that fish grazing caused a reduction in biomass and change in domination structure from diatoms to filamentous cyanobacteria. Our results showed that the abundance of small diatom species belonging to Achnanthaceae correlated positively with abundance of fish, which suggests their resistance to fish grazing. The sensitivity to grazing of larger taxa belonging, for 
example, to Fragilariaceae may be expected, as their abundance correlated negatively with fish abundance. The direct periphytic biomass consumption by omnivorous fish was showed in experimental study by Guariento et al. (2010). Blanco et al. (2008) showed that zooplanktivorous fish enhanced the abundance of Euglenophyceae and Zygnematophyceae, as well as algal species richness and diversity, by secreting biogenic substances. Our studies showed that the abundance of crustaceans being able to graze on algae was very low, and no significant relationship between them and epiphytic algae was found. Reports on grazing on epiphytic algae by zooplankton are very scarce (Tall et al., 2006), which suggests lower significance of planktonic crustaceans than other invertebrates on grazing algae (France et al., 1991). In general, in temperate lakes, invertebrate grazer communities are mostly dominated by chironomid larvae, with their total biomass increasing with epiphyton biomass (Liboriussen and Jeppesen, 2006; Tarkowska-Kukuryk, 2013). This finding and our results suggest higher grazing pressure of fish than that of invertebrates. In the studied lakes, the highest pressure occurred in Lake Krzczeń, followed by Lakes Tomaszne and Czarne Sosn. The lowest pressure occurred in Lake Skomielno. Further field and experimental studies on the relationships between epiphyton and fish and zooplankton grazers are highly essential.

Among nutrients, the molar DIN/DIP ratio and $\mathrm{N}-\mathrm{NO}_{3}$ concentration seemed to be more important for epiphytic algal abundance and composition than $\mathrm{P}_{\text {tot. }}$ and $\mathrm{P}-\mathrm{PO}_{4}$ concentrations. This seems to confirm the finding of an experiment by Liboriussen and Jeppesen (2006) that the concentrations of individual nutrients alone are poor predictors of the standing biomass and production of epiphytic algae. Elemental ratios of $\mathrm{C}: \mathrm{N}: \mathrm{P}$ are commonly used to determine whether nitrogen or phosphorus most limit algal accumulation, based on the 106:16:1 ratio (Redfield, 1958). In general, N:P ratio has a significant influence on algal biomass in lakes, and this effect is greatest at high concentration of total phosphorus (Downing and McCauley, 1992), detected particularly in the hypertrophic Lake Krzczeń. During a study performed in 30 upland lakes (Maberly et al., 2002), the DIN/DIP ratio (next to DIN) appeared to be the primary environmental factor controlling the extent of nitrogen or phosphorus limitation. Song et al. (2007) suggested that elevated levels of both phosphorus and nitrogen lead to excessive epiphyton growth, but according to Bowes et al. (2007), nutrient enrichment may have small or even negative effects on algal growth. These discrepancies can be explained by the recent findings (Zhang and Mei, 2013) that various algal species react differently to changing environmental conditions, and thus different responses of epiphytic algae to nutrients may occur as well. A study performed in 44 shallow European lakes (Blanco et al., 2014) revealed significant effects of other physical and biological factors, such as conductivity and pelagic chl-a, on the configuration of epiphytic diatom assemblages. In this study, we found a negative relationship between phytoplankton chl-a and epiphytic cyanobacteria, Fragilariaceae and Chlorophyceae.

Water transparency, next to frequency of WLFs, also influenced the structure of algal communities in the studied lakes. Both low and strong light inhibits algal development. Lalonde and Downing (1991) observed an increase in epiphyton biomass with the depth in oligotrophic lakes and a decrease with depth in eutrophic water bodies. Moreover, Vadeboncoeur and Steinman (2002) observed that there was a decrease in the influence of nutrient supply on epiphyton under low light conditions, presumably because lower photosynthetic rates decrease the demand for nutrients.

Also phytoplankton development may play an important role in epiphyton development and composition (Hansson, 1992; Liboriussen and Jeppesen, 2003). Cyanobacterial blooms, observed in Lakes Krzczeń and Tomaszne (PawlikSkowrońska and Toporowska, 2016), affected water transparency, deteriorating light conditions, and, in the consequence, caused epiphyton shading. But the next very important interaction could be higher nutrient uptake rates from the water column of planktonic algae in comparison with epiphytes (Vadeboncoeur and Steinman, 2002). Thus, in the studied highly eutrophic lakes, proliferating planktonic algae (mostly cyanobacteria) might be permanent strong competitors for epiphyton as was stated previously by Hansson (1992).

\section{Conclusion}

Our study highlights that due to the complexity of factors shaping epiphyton development and composition, both bottomup and top-down forces, as well as some lake disturbances, for example frequency of WLFs and water blooms, should be analyzed simultaneously. We showed that in the shallow lakes with water management, the frequency of WFLs may be one of the most important factors shaping epiphyton assemblages on common reed. From among top-down forces, grazing pressure of fish was much more important than that of littoral crustaceans. Among bottom-up abiotic factors controlling the development of epiphytic algal communities, at similar water temperature and high nutrient concentrations, the DIN/DIP ratio (stronger than particular nutrients) and light conditions (water transparency) were found to be the most significant. Mass development of phytoplankton and cyanobacterial blooms might also play an important role in highly eutrophic lakes. Taking our findings together, we may conclude, that nowadays man-made alterations have strong influence on the development of epiphytic algae in shallow lakes ecosystems. Further complex studies are strongly required to learn about the structure and functionality of epiphytic assemblages and analyze the forces that modulate them to predict future changes in a human- and climatically-impacted world.

Acknowledgments. Thanks are expressed to W. Płaska for help in fish collection.

\section{References}

Abe S, Uchida K, Nagumo T, Tanaka J. 2007. Alterations in the biomass-specific productivity of periphyton assemblages mediated by fish grazing. Freshwater Biol 52: 1486-1493.

Appelberg M. 2000. Swedish standard methods for sampling freshwater fish with multi-mesh gillnets: stratified random sampling with Nordic multi-mesh gillnets provide reliable whole-lake estimates of the relative abundance and biomass of freshwater temperate lakes. Sweden: Fiskeriverket Information.

Barbour MT, Gerritsen J, Snyder DB, Stribling JB. 1999. Rapid bioassessment protocols for use in streams and wadeable rivers: 
periphyton, benthic macroinvertebrates and fish. Washington: United States Environmental Protection Agency.

Blanco S, Romo S, Fernández-Aláez M, Bécares E. 2008. Response of epiphytic algae to nutrient loading and fish density in a shallow lake: a mesocosm experiment. Hydrobiologia 600: 65-76.

Blanco S, Cejudo-Figueiras C, Álvarez-Blanco I. 2014. Epiphytic diatoms along environmental gradients in Western European shallow lakes. CLEAN-Soil Air Water 42: 229-235.

Bowes MJ, Smith JT, Hilton J, Sturt MM, Armitage PD. 2007. Periphyton biomass response to changing phosphorus concentrations in a nutrient impacted river: a new methodology for phosphorus target setting. Can J Fish Aquat Sci 64: 227-238.

Carlson RE. 1977. A trophic state index for lakes. Limnol Oceanogr 22: $361-369$.

Cattaneo A, Galanti G, Gentinetta S, Romo S. 1998. Epiphytic algae and macroinvertebrates on submerged and floating-leaved macrophytes in an Italian lake. Freshwater Biol 39: 725-740.

Cox EJ. 1996. Identification of freshwater diatoms from live material. London: Chapman and Hall, $156 \mathrm{p}$.

Dawidek J, Sobolewski S, Turczyński M. 2004. Transformations of catchment-areas of lakes converted into storage reservoirs in the Wieprz-Krzna Canal system. Limnol Rev 4: 67-74.

de Normalisation CE. 2005. Water Quality-Sampling of Fish with Multi-Mesh Gillnets (EN 14757). Brussels: European Committee for Standardization.

DIN EN ISO 29441. 2010. Water quality - Determination of total nitrogen after UV digestion - Method using flow analysis (CFA and FIA) and spectrometric detection. 29441.

Downing JA, McCauley E. 1992. The nitrogen: phosphorus relationship in lakes. Limnol Oceanogr 37: 936-945.

de Souza ML. Pellegrini BG, Ferragut C. 2015. Periphytic algal community structure in relation to seasonal variation and macrophyte richness in a shallow tropical reservoir. Hydrobiologia 755: 183-196.

Erhard D. Gross EM. 2006. Allelopathic activity of Elodea canadensis and Elodea nuttallii against epiphytes and phytoplankton. Aquat Bot 85: 203-211.

France RL, Howell ET, Paterson MJ, Welbourn PM. 1991. Relationship between littoral grazers and metaphytic algae in five softwater lakes. Hydrobiologia 220: 9-27.

Gross EM, Feldbaum C, Graf A. 2003. Epiphyte biomass and elemental composition on submersed macrophytes in shallow eutrophic lakes. Hydrobiologia 506: 559-565.

Guariento RD, Carneiro LS, Caliman A, Bozelli RL, Leal JJF, Esteves FDA. 2010. Interactive effects of omnivorous fish and nutrient loading on net productivity regulation of phytoplankton and periphyton. Aquatic Biol 10: 273-282.

Hansson LA. 1992. Factors regulating periphytic algal biomass. Limnol Oceanogr 37: 322-328.

Hillebrand H. 2002. Top-down versus bottom-up control of autotrophic biomass - a meta-analysis on experiments with periphyton. J North Am Benthological Soc 21: 349-369.

Hillebrand H, Dürselen CD, Kirschtel D, Pollingher U, Zohary T. 1999. Biovolume calculation for pelagic and benthic microalgae. $J$ Phycol 35: 403-424.

Hofmann G. 1994. Epiphytic diatoms in lakes and their utility as indicators of trophy, J. Cramer. Berlin, Stuttgart: Bibliotheca Diatomologica, 241 p. (in German).

Karosienė J, Kasperovičienè J. 2008. Seasonal succession of epiphyton algal communities on Phragmites australis (Cav.) Trin. ex Stend. in a mesoeutrophic lake. Ekologija 54: 32-39.

Kernan MR, Battarbee RW, Moss B. 2010. Climate change impacts on freshwater ecosystems, Vol. 314. Oxford: Wiley-Blackwell.
Kitner M, Poulícková A, 2003. Littoral diatoms as indicators for the eutrophication of shallow lakes. Hydrobiologia 506: 519-524.

Komárek J. 2013. Cyanoprokaryota 3: Heterocytous Genera. In: Budel B, Gartner G, Krienitz L, Schagerl M, eds. Süßwasserflora von Mitteleuropa, 19/3. Berlin: Spektrum Akademischer Verlag, $1131 \mathrm{p}$.

Komárek J, Anagnostidis K. 1999. Chroococcales T 1. In: Ettl H, Gärtner G, Gerloff J, Heyning H, Mollenhauer D, eds. Süßwasserflora von Mitteleuropa. Heidelberg, Berlin: Spektrum Akademischer Verlag, GmbH, 548 p.

Komárek J, Anagnostidis K. 2000. Chroococcales T 1. In: Ettl H, Gärtner G, Gerloff J, Heyning H, Mollenhauer D, eds. Süßwasserflora von Mitteleuropa. Heidelberg, Berlin: Spektrum Akademischer Verlag, GmbH, 548 p.

Komárek J, Anagnostidis K. 2005. Oscillatoriales. T 2. In: Ettl H, Gärtner G, Gerloff J, Heyning H, Mollenhauer D, eds. Süßwasserflora von Mitteleuropa. München: Spektrum Akademischer Verlag, $759 \mathrm{p}$.

Komárek J, Fott B. 1983. Chlorophyceae (Grünalgen) Ordnung: Chlorococcales. In: Huber-Pestalozzi G, ed. Das Phytoplankton des Süßfwassers, 7(1). Stuttgart: Schweizerbart.

Krammer K, Lange-Bertalot H. 2004a. Bacillariophyceae. 4. Achnanthaceae, Kritische Ergänzungen zu Achnanhtes s. 1., Navicula s. str., Gomphonema. In: Ettl H, Gerloff J, Heynig H, Mollenhauer D, eds. Süsswasserflora von Mitteleuropa, Bacillariophyceae. Berlin, Gustav Fischer: Spectrum Akademischer Verlag, $468 \mathrm{p}$.

Krammer K, Lange-Bertalot H. 2004b. Bacillariophyceae. 3. Centrales, Fragilariaceae, Eunotiaceae. In: Ettl H, Gerloff J, Heyning H, Mollenhauer D, eds. Süsswasserflora von Mitteleuropa. Berlin, Gustav Fischer: Spektrum Akademischer Verlag, $598 \mathrm{p}$.

Krammer K, Lange-Bertalot H. 2007a. Bacillariophyceae. 2. Bacillariaceae, Epithemiaceae, Surirellaceae. In: Ettl H, Gerloff J,Heyning H, Mollenhauer D, eds. Süsswasserflora von Mitteleuropa. München: Spektrum Akademischer Verlag.

Krammer K, Lange-Bertalot H. 2007b. Bacillariophyceae. 1. Naviculaceae. In: Ettl H, Gerloff J, Heyning H, Mollenhauer D, eds. Süsswasserflora von Mitteleuropa, 2(1). München: Spektrum Akademischer Verlag.

Kufel L, Pasztaleniec A, Czapla G, Strzałek M. 2007. Constitutive allelochemicals from Stratiotes aloides L. affect both biomass and community structure of phytoplankton. Pol J Ecol 55: 387-393.

Lalonde S, Downing JA. 1991. Epiphyton biomass is related to lake trophic status, depth, and macrophyte architecture. Can J Fish Aquat Sci 48: 2285-2291.

Laugaste R, Reunanen M. 2005. The composition and density of epiphyton on some macrophyte species in the partly meromictic Lake Verevi. Hydrobiologia 182: 137-150.

LeGresley M, McDermott G. 2010. Counting chamber methods for quantitative phytoplankton analysis-haemocytometer, PalmerMaloney cell and Sedgewick-Rafter cell. Microscopic and molecular methods for quantitative phytoplankton analysis. UNESCO (IOC Manuals and Guides), pp. 25-30.

Leira M, Cantonati M. 2008. Effects of water-level fluctuations on lakes: an annotated bibliography. Hydrobiologia 613: 171-184.

Liboriussen L, Jeppesen E. 2003. Temporal dynamics in epipelic, pelagic and epiphytic algal production in a clear and a turbid shallow lake. Freshwater Biol 48: 418-431.

Liboriussen L, Jeppesen E. 2006. Structure, biomass, production and depth distribution of periphyton on artificial substratum in shallow lakes with contrasting nutrient concentrations. Freshwater Biol 51: 95-109. 
Lowe RL. 1996. Periphyton patterns in lakes. In Stevenson RJ, Bothwell ML, Lowe RL, eds.Algal ecology: freshwater benthic ecosystems. San Diego: Academic Press, pp. 57-76.

Maberly SC, King L, Dent MM, Jones RI, Gibson CE, 2002. Nutrient limitation of phytoplankton and periphyton growth in upland lakes. Freshwater Biol 47: 2136-2152.

Messyasz B, Kuczyńska-Kippen N. 2006. Periphytic algal communities: a comparison of Typha angustifolia L. and Chara tomentosa L. beds in three shallow lakes (West Poland). Pol J Ecol 54: 15-27.

Mieczan T, Adamczuk M, Tarkowska-Kukuryk M, Nawrot D. 2016. Effect of water chemistry on zooplanktonic and microbial communities across freshwater ecotones in different macrophyte-dominated shallow lakes. J Limnol 75: 262-274.

Pawlik-Skowrońska B, Toporowska M. 2016. How to mitigate cyanobacterial blooms and cyanotoxin production in eutrophic water reservoirs? Hydrobiologia 778: 45-59.

Pfeiffer TŽ, Mihaljević M, Špoljarić D, Stević F, Plenković-Moraj A. 2015. The disturbance-driven changes of periphytic algal communities in a Danubian floodplain lake. Knowl Manag Aquat Ecosyst 416: 02.

PN-EN 872. 1994. Water quality - Determination of suspensions The method using filtration through glass fiber filters. Warsaw: PKN.

PN-C-04576-4. 2004. Water and sewage - Studies on the content of nitrogen compounds - Determination of ammonium nitrogen in water by direct nesslerization. Warsaw: PKN.

PN-EN ISO 6878. 2004. Water quality - Determination of phosphorus - Ammonium molybdate spectrometric method. Warsaw: PKN.

PN-ISO 10260. 2002. Water quality. Measurement of biochemical parameters. Spectrophotometrical determination of chlorophyll-a concentration. Warsaw: PKN.

Poulíčková A, Kitner M, Hašler P. 2006. Vertical distribution of attached algae in shallow fishponds of different trophic status. Biologia 61: 1-9.

Redfield AC. 1958. The biological control of chemical factors in the environment. Am Sci 46: 205-221.

Reynolds CS. 2006. The ecology of phytoplankton. Cambridge UK: Cambridge University Press.

Rodríguez P, Tell G, Pizarro H. 2011. Epiphytic algal biodiversity in humic shallow lakes from the Lower Paraná River Basin (Argentina). Wetlands 31: 53-63.

Round FE. 1991. Diatoms in river water-monitoring studies. $J$ Applied Phycol 3: 129-145.
Sender J. 2012. Aquatic and rush macroflora. In Kornijów R, Buczyński P, eds.Lake Skomielno (Łęczna-Włodawa Lakeland, Eastern Poland). Environment monography, pp. 83-20.

Sender J. 2016. The effect of riparian forest shade on the structural characteristics of macrophytes in a mid-forest lake. AEER 14: 249-261.

Shannon CE, Weaver W. 1949. The mathematical theory of communication. Urbana, Illinois: University of Illinois Press.

Song YZ, Qin BQ, Gao G. 2007. Effect of nutrient on periphytic algae and phytoplankton. J Lake Sci 19: 125-130.

Suchora M. 2012. Physiogeographical description of the lake and its vicinity. Location, geology, geomorphology, and climate. In: Kornijów R, Buczyński P, eds. Lake Skomielno (Łęczna-Włodawa Lakeland, Eastern Poland). Environment monography, pp. 10-20.

Takashi A, Munira S, Jagath M, Takeshi F. 2004. The effect of epiphytic algae on the growth and production of Potamogeton perfoliatus $\mathrm{L}$. in two light conditions. Environ Exper Bot 52: 225-238.

Tall L, Cloutier L, Cattaneo A. 2006. Grazer-diatom size relationships in an epiphytic community. Limnol Oceanogr 51: 1211-1216.

Tarkowska-Kukuryk M. 2013. Periphytic algae as food source for grazing chironomids in a shallow phytoplankton dominated lake. Limnologica 43: 254-264.

ter Braak CJF, Šmilauer P. 2002. CANOCO reference manual and user's guide to Canoco for Windows: software for Canonical community ordination (version 4.5). Ithaca, NY, USA: Microcomputer Power.

Toporowska M, Pawlik-Skowrońska B, Wojtal AZ. 2008. Epiphytic algae on Stratiotes aloides L., Potamogeton lucens L., Ceratophyllum demersum L. and Chara spp. in a macrophyte-dominated lake. Oceanol Hydrobiol Stud 37: 51-63.

Vadeboncoeur Y, Kalff J, Christoffersen K, Jeppesen E. 2006. Substratum as a driver of variation in periphyton chlorophyll and productivity in lakes. J North Am Benthological Soc 25: 379-392.

Vadeboncoeur Y, Steinman AD. 2002. Periphyton function in lake ecosystems. Sc World J 2: 1449-1468.

Van den Hoek C, Mann DG, Jahns HM. 1995. Algae. An introduction to phycology. Cambridge: Cambridge Univ. Press, 623 p.

Weis JS, Weis P. 2003. Is the invasion of the common reed, Phragmites australis, into tidal marshes of the eastern US an ecological disaster? Mar Pollut Bull 46: 816-820.

Zhang X, Mei X. 2013. Periphyton response to nitrogen and phosphorus enrichment in a eutrophic shallow aquatic ecosystem. CJOL 31: 59-64.

Cite this article as: Toporowska M, Rechulicz J, Adamczuk M, Niedźwiecki M. 2018. The role of abiotic and biotic environmental factors in shaping epiphyton on common reed in shallow, hydrologically transformed, temperate lakes. Knowl. Manag. Aquat. Ecosyst., $419,18$. 